\title{
EVALUASI PENGELOLAAN HUTAN KEMASYARAKATAN (HKM) \\ DAN PERUBAHAN TUTUPAN LAHAN PADA AREAL IZIN USAHA PEMANFAATAN HUTAN KEMASYARAKATAN (IUPHKM) DESA UJAN MAS ATAS KABUPATEN KEPAHIANG
}

\author{
Weli Sulastri ${ }^{1)}$, Hery Suhartoyo ${ }^{2)}$, Yansen ${ }^{3)}$ \\ ${ }^{1)}$ Program Pascasarjana Pengelolaan Sumber Daya Alam dan Lingkungan, Fakultas \\ Pertanian, Universitas Bengkulu \\ 1) Dinas Lingkungan Hidup dan Kehutanan Provinsi Bengkulu \\ ${ }^{2)}$ Jurusan Kehutanan Fakultas Pertanian Universitas Bengkulu \\ 3) Jurusan Ilmu Tanah Fakultas Pertanian Universitas Bengkulu
}

\begin{abstract}
ABSTRAK
Indikator keberhasilan program HKm adalah adanya perbaikan tutupan hutan. HKm dapat dikatakan berhasil apabila secara umum kondisi hutan semakin baik sesuai fungsinya dan secara ekonomi kesejahteraan petani $\mathrm{HKm}$ juga membaik. Beberapa kendala yang menyebabkan belum berhasilnya pelaksanaan HKm untuk mensejahterakan masyarakat di sekitar hutan diantaranya adalah luas garapan yang tidak sesuai dengan jumlah peserta, sistem usaha tani yang masih sederhana, kemampuan swadaya masyarakat yang relatif kecil sehingga lebih cenderung ke tanaman semusim, serta pengelolaan masih on farm dan belum memperhatikan input, pascapanen dan pemasaran. Tujuan dari penelitian ini adalah mengevaluasi aspek kelembagaan, teknis, sosial ekonomi dan ekologi serta membandingkan perubahan tutupan lahan pada IUPHKm Desa Ujan Mas Atas, Kecamatan Kepahiang, Kabupaten Kepahiang pada tahun 2005, 2010 dan tahun 2015. Penelitian ini dilaksanakan di IUPHKm Desa Ujan Mas Atas, Kecamatan Ujan Mas, Kabupaten Kepahiang. Metode penelitian dilakukan dengan metode observasi dan wawancara dan data untuk perubahan tutupan lahan dikumpulkan dengan cara analisis spasial. Batasan penelitian meliputi aspek kelembagaan, aspek teknik, aspek sosial, ekonomi, ekologi serta batasan perubahan tutupan lahan. Hasil penelitian yang diperoleh bahwa evaluasi $\mathrm{HKm}$ menunjukkan indikator baik dengan total skor yang diperoleh antara 67,25-67,50. Berdasarkan ketiga aspek yang dievaluasi semua mempunyai kisaran nilai baik dari aspek kelembagaan dengan skor 28,2528,50 (baik), aspek teknis dengan skor 24 (sedang), serta aspek sosial, ekonomi dan ekologi dengan skor 15 (baik). Untuk tipe penutupan lahan yang diperoleh yaitu kebun campuran dan tegalan, dimana dalam kebun campuran ditanami tanaman keras lebih dari satu jenis atau tidak seragam yang menghasilkan bunga, buah, serta getah dan cara pengambilan hasilnya bukan dengan cara menebang pohon dan tegalan digunakan untuk kegiatan pertanian dengan jenis tanaman semusim.
\end{abstract}

Kata Kunci : evaluasi pengelolaan hutan kemasyarakatan, perubahan tutupan lahan, izin usaha pemanfaatan hutan kemasyarakat

\section{PENDAHULUAN}

Merujuk pada definisi yang
tertuang dalam UU No 4 tahun 2009
tentang Pertambangan Mineral dan
Batubara, pascatambang diartikan sebagai

kegiatan setelah akhir sebagian atau seluruh kegiatan usaha pertambangan untuk memulihkan fungsi lingkungan dan fungsi sosial. Untuk mewujudkan pembangunan berkelanjutan, kegiatan usaha pertambangan harus dilaksanakan 
dengan memperhatikan prinsip lingkungan hidup, transparansi dan partisipasi masyarakat. Prinsip pengelolaan lingkungan hidup meliputi perlindungan terhadap kualitas air permukaan, air tanah, air laut, dan udara sesuai dengan standar baku mutu lingkungan hidup dan ketentuan peraturan perundang-undangan.

Berdasarkan Surat Keputusan

Menteri Kehutanan Republik Indonesia nomor SK.784/Menhut-II/2012, luas kawasan hutan di Provinsi Bengkulu adalah \pm 924.631 ha atau $46,42 \%$ dari total daratan Provinsi Bengkulu yang luasnya 1.991.933 ha (Badan Pusat Statistik Provinsi Bengkulu, 2017). Berdasarkan Peraturan Gubernur Bengkulu nomor 36 Tahun 2013 tentang Rencana Kehutanan Tingkat Provinsi Bengkulu Tahun 20142033, luas kawasan hutan lindung di Kabupaten Kepahiang adalah 9.244,96 ha. Hutan lindung ini meliputi, Hutan Lindung Bukit Balai Rejang 1.159,72 ha, Hutan Lindung Rimbo Donok 362,16 ha, Hutan Lindung Konak 12,52 ha dan Kelompok Hutan Lindung Bukit Daun 7.710,56 ha. Kelompok Hutan Lindung Bukit Daun terletak di Kecamatan Kepahiang, Kecamatan Ujan Mas dan Kecamatan Seberang Musi. Luas kawasan Hutan Lindung Bukit Daun telah mengalami deforestasi $\pm 70 \%$ dengan laju deforestasi dari tahun 2011 sampai $2015 \pm 200$ ha per tahun (Kementerian Lingkungan Hidup dan Kehutanan, 2016a). Kerusakan Hutan Lindung Bukit Daun di Kecamatan Kepahiang dan Kecamatan Ujan Mas mencapai 417 ha pada tahun 2017 (Dinas Lingkungan Hidup dan Kehutanan Provinsi Bengkulu, 2017).

Pemerintah mendorong program perhutanan sosial untuk melegalkan akses masyarakat sekitar hutan dapat mengelola/memanfaatkan kawasan hutan. Program perhutanan sosial tersebut berupa Hak Pengelolaan Hutan Desa (HPHD), Izin Usaha Pemanfaatan Hutan Kemasyarakatan (IUPHKm), Hutan Tanaman Rakyat (HTR), Kemitraan Kehutanan atau Pengakuan Dan
Perlindungan Masyarakat Hukum Adat untuk kesejahteraan masyarakat dan kelestarian sumberdaya hutan (Kementerian Lingkungan Hidup dan Kehutanan, 2016b). Penyelenggaraan HKm dimaksudkan untuk pengembangan kapasitas dan memberikan akses terhadap masyarakat setempat untuk memecahkan persoalan ekonomi dan sosialyang terjadi di masyarakat.

$$
\text { Kelurahan Ujan Mas Atas, }
$$

Kecamatan Ujan Mas, Kabupaten Kepahiang merupakan salah satu daerah yang mendapatkan IUPHKm selama 35 tahun. Masyarakat yang mengelola $\mathrm{HKm}$ di Kecamatan Ujan Mas terdiri dari 9 (Sembilan) kelompok tani dengan luas 318.5 ha. Kawasan hutan yang diberikan IUPHKm tersebut merupakan Hutan Lindung Bukit Daun. Melalui izin tersebut, pemerintah berupaya melibatkan masyarakat sekitar hutan sebagai mitra dalam melakukan pengelolaan hutan untuk meningkatkan kesejahteraan masyarakat setempat melalui pemanfaatan sumberdaya hutan secara optimal, adil dan berkelanjutan dengan tetap menjaga kelestarian fungsi hutan dan lingkungan hidup.

Mengkaji apakah pelaksanaan kegiatan HKm Desa Ujan Mas Atas telah dilaksanakan sesuai dengan rencana dan tujuan yang ingin dicapai, hal-hal yang menjadi kendala dalam pengelolaan $\mathrm{HKm}$ dan bagaimanakah kondisi tutupan lahan setelah adanya pengelolaan HKm maka dilakukan penelitian ilmiah untuk mengevaluasi pengelolaan IUPHKm DesaUjan Mas Atas, Kecamatan Ujan Mas, Kabupaten Kepahiang. Tujuan penelitian ini adalah mengevaluasi aspek kelembagaan, teknis, sosial ekonomi dan ekologi serta membandingkan perubahan tutupan lahan pada IUPHKm Desa Ujan Mas Atas, Kecamatan Kepahiang, Kabupaten Kepahiang pada tahun 2005, 2010 dan tahun 2015.

\section{METODE PENELITIAN}




\section{Lokasi, waktu dan alat penelitian}

Penelitian ini dilaksanakan di IUPHKm Desa Ujan Mas Atas, Kecamatan Ujan Mas, Kabupaten Kepahiang dengan luas areal 318, 5 ha yang lokasinya berada dalam satu kesatuan bentang alam atau hamparan. Penelitian dilaksanakan selama 2 (dua) bulan mulai bulan Mei sampai dengan bulan Juni 2018. Alat yang digunakan adalah alat tulis, kamera, GPS computer/laptop, kalkulator, panduan wawancara berupa kuisioner, peta RBI, peta kawasan hutan, peta areal kerja $\mathrm{HKm}$ dan peta hasil interpretasi citra satelit.

\section{Batasan penelitian}

\section{Aspek kelembagaan}

Aspek kelembagaan meliputi bentuk kelompok, struktur organisasi kelompok, keanggotaan kelompok, areal kelola kelompok, keorganisasian kelompok, program kerja kelompok dan kemandirian kelompok.

\section{Aspek teknis}

Aspek teknis adalah aspek pengelolaan yang meliputi rehabilitasi pada blok budidaya yang berupa lahan terbuka, rehabilitasi pada blok budidaya yang sudah berupa kebun dan pengamanan blok perlindungan.

\section{Aspek sosial, ekonomi dan ekologi}

Aspek sosial meliputi kepastian hak kelompok, hubungan masyarakat kelompok $\mathrm{HKm}$ dengan pemerintah dan pihak lain dan tertib sosial pengelolaan sesuai dengan aturan kelompok. Aspek ekonomi meliputi pendapatan anggota kelompok, kontribusi kepada pemerintah dalam pembangunan dan usaha ekonomi kelompok. Aspek ekologi meliputi biofisik, keragaman tanaman, dan ketersediaan sumber air.

\section{Batasan perubahan tutupan lahan}

Perubahan tutupan lahan yang diteliti dalam penelitian ini adalah perubahan tutupan lahan di IUPHKm Desa Ujan Mas Atas pada tahun 2005, 2010 dan tahun 2015. Tipe penutupan lahan pada lokasi penelitian ini adalah pertanian lahan kering campur yang terdiri dari kebun campuran dan tegalan.

\section{Metode Pengambilan Sampel}

Jumlah populasi kelompok HKm Desa Ujan Mas Atas dalam penelitian ini berjumlah 229 (dua ratus dua puluh sembilan) KK terdiri dari 9 (sembilan) kelompok tani. Pengambilan sampel untuk penelitian yang populasi lebih dari 100 orang maka batas error yang digunakan adalah 10-15\% (Arikunto, 2011). Dalam penelitian ini batas error yang digunakan dalam pengambilan sampel adalah 15\% dan penentuan jumlah sampel dilakukan berdasarkan formula Slovin (Soewadji, 2012), dengan rumus sebagai berikut :

$$
\mathrm{n}=\frac{\mathrm{N}}{\mathrm{N}(\mathrm{e})^{2}+1}
$$

Keterangan :

$\mathrm{n} \quad=$ jumlah sampel responden yang diambil dalam penelitian

$\mathrm{N} \quad=$ jumlah populasi petani anggota kelompok HKm

$\mathrm{E} \quad=$ batas error

$1=$ bilangan konstan

Jadi, perhitungan jumlah sampel kelompok Hkm Desa Ujan Mas Atas, Kecamatan Ujan Mas, Kabupaten Kepahiang adalah :

$$
\begin{gathered}
n=\frac{229}{229(0,15)^{2}+1} \\
n=37 \text { responden }
\end{gathered}
$$

Pengambilan sampel menggunakan metode simple random sampling, karena pengambilan sampel dilakukan secara acak tanpa memperhatikan strata yang ada kelompok HKm Desa Ujan Mas Atas (Sugiono, 2015). Perhitungan jumlah sampel pada 
tiap kelompok menggunakan rumus yaitu

$$
\mathrm{ni}=\frac{\mathrm{Ni}}{\mathrm{N}} \times \mathrm{n}
$$

$$
\begin{array}{ll}
\mathrm{n} & =\text { banyaknya sampel } \\
\mathrm{ni} & =\text { banyaknya sampel ke-i } \\
\mathrm{N} & =\text { jumlah seluruh populasi } \\
\mathrm{Ni} & =\text { banyaknya populasi ke-i }
\end{array}
$$

Keterangan :

Tabel 1. Jumlah sampel pada tiap kelompok

\begin{tabular}{llcc}
\hline \multicolumn{1}{c}{ No. } & Nama Kelompok tani & Jumlah Anggota (orang) & Jlh sampel \\
\hline 1. & Sematung I & 26 & 4 \\
2. & Pinang Jaya & 15 & 2 \\
3. & Kali Musi & 25 & 4 \\
4. & Tiga serangkai & 30 & 5 \\
5. & Sematung II & 25 & 4 \\
6. & Usaha Maju & 29 & 5 \\
7. & Penado & 26 & 4 \\
8. & Tunas Muda & 29 & 5 \\
9. & Tanah Tua & 24 & 4 \\
\hline Jumlah & & 229 & 37 \\
\hline
\end{tabular}

\section{Metode penelitian dan analisis data}

Metode yang digunakan pada penelitian ini diadaptasi dari pedoman monitoring dan evaluasi penyelenggaraan $\mathrm{HKm}$ seperti yang digunakan di Kabupaten Lampung Barat sesuai SK Bupati Lampung Barat nomor 11 Tahun 2004 tentang Panduan Teknis Indikator dan Kriteria Monitoring dan Evaluasi Pelaksanaan Program Hutan Kemasyarakatan di Kabupaten Lampung Barat. Data yang terkumpul selanjutnya ditabulasi dan dianalisis untuk mendapatkaan ukuran evaluasi yang didasarkan pada :

a. Sistem skoring, yaitu didasarkan pada bobot masing-masing aspek yang dibagi secara berimbang sesuai jumlah pertanyaan dalam kuisioner. Nilai skor masing-masing aspek dapat dilihat pada Tabel 2.

b. Penilaian kondisi HKm sesuai aspek pengelolaan sesuai kelasnya didasarkan

\begin{tabular}{|c|c|c|c|c|}
\hline No & Aspek Pengelolaan HKm & $\begin{array}{c}\text { Jlh } \\
\text { skor }\end{array}$ & Kisaran skor & Kelas skor \\
\hline \multirow[t]{3}{*}{1.} & Kelembagaan & 40 & $28-40$ & Baik \\
\hline & & & $14-27$ & Sedang \\
\hline & & & $0-13$ & Buruk \\
\hline \multirow[t]{3}{*}{2.} & Teknik & 40 & $28-40$ & Baik \\
\hline & & & $14-27$ & Sedang \\
\hline & & & $0-13$ & Buruk \\
\hline \multirow[t]{3}{*}{3.} & Sosial, ekonomi dan ekologi & 20 & $14-20$ & Baik \\
\hline & & & $7-13$ & Sedang \\
\hline & & & $0-6$ & Buruk \\
\hline
\end{tabular}
pada hasil perhitungan skor total. Adapun klasifikasinya dapat dilihat pada Tabel 3.

Tabel 2. Nilai skor masing-masing aspek pengelolaan HKm

(Sumber : SK Bupati Lampung Barat Nomor 225 tahun 2005) 
Tabel 3. Klasifikasi HKm berdasarkan skor

\begin{tabular}{|c|c|c|}
\hline No. & Kelas skor & Kisaranskor \\
\hline 1. & Baik & $61-100$ \\
\hline 2. & Sedang & $31-60$ \\
\hline 3. & Buruk & $0-30$ \\
\hline
\end{tabular}

(Sumber : SK Bupati Lampung Barat Nomor 225 tahun 2005)

Metode analisis untuk laju perubahan tutupan lahan menggunakan analisis spasial GIS dengan cara membandingkan peta tutupan lahan tahun 2005, 2010 dan 2015. Hal ini dilakukan untuk membandingkan laju perubahan tutupan lahan yang terjadi pada tahun 2005, 2010 dan 2015.

\section{HASIL DAN PEMBAHASAN}

\section{Ekologi}

Sumber air

Data sumber air yang terdapat di IUPHKm Desa Ujan Mas Atas adalah Smt I ada 8 , PJ ada $3, \mathrm{KM}$ ada 6 , TS ada 6 , Smt II ada 6, UM ada 5, Pnd ada 5, TM ada 1 , TT ada 5 .

Ket : Smt I (Sematung I), PJ (Pinang Jaya), KM (Kali Musi), TS (Tiga serangkai), Smt II (Sematung II), UM (Usaha Maju), Pnd (Penado), TM (Tunas Muda), TT (Tanah Tua)

Dari data tersebut areal IUPHKm

Desa Ujan Mas Atas memiliki ketersediaan sumber air cukup banyak, sehingga petani tidak akan kesulitan untuk mendapatkan air dalam memenuhi kebutuhan hidup maupun kegiatan dalam pengelolaan $\mathrm{HKm}$ tersebut. Banyaknya sumber air yang tersedia menjadi indikator bahwa masih terjaganya ekosistem pada IUPHKm Desa Ujan Mas Atas yang dulunya merupakan hutan lindung. Sejalan dengan pendapat Manan (1976) dalam Sulistyorini et al. (2016) bahwa ketersediaan air baik secara kualitas maupun kuantitas berkaitan erat dengan kualitas hutan atau dengan kata lain kualitas air merupakan salah satu indikator kondisi hutan.

\section{Pola Pemanfaatan Lahan HKm Ujan Mas Atas}

Hasil observasi di areal IUPHKm Desa Ujan Mas Atas diketahui jenis tanaman yang ada adalah tanaman pertanian seperti kopi (Coffea canephora), pala (Myristica fragrans), cabe besar (Capsicum annum L), cabe rawit (Capsicum frutescens), lada (Piper ningrum), aren (Arenga pinata), bambu (Dendrocalamus sp.), jengkol (Archidendron pauciflorum), alpukat (Persea americana), mangga (Mangifera indica), pinang (Areca catechu L.) dan jahe (Zingiber officinale). Sedangkan tanaman kayu yang ada adalah surian (Toona sureni Merr), durian (Durio zibethinus), johar (Senna siamea), karet (Hevea brasiliensis), kemiri (Aleurites moluccanus), merambung (Vernonia arborea Schreb.Ham), meranti merah (Shorea pinanga), nangka (Artocarpus heterophyllus), dan petai (Leucaena leucocephala). 
P-ISSN: 2302- 6715

E- ISSN: 2654-7732

Masyarakat yang mengelola $\mathrm{HKm}$ pada umumnya menjadikan pemanfaatan lahan sebagai sumber penting bahkan menjadi sumber mata pencaharian yang utama untuk memenuhi kehidupan seharihari. Pola tanam yang digunakan masyarakat rata-rata dengan sistem agroforestry. Karakteristik pola tanam agroforestry sangat tergantung pada pemilik lahan serta karakteristik lahannya. 



\section{Evaluasi Pengelolaan HKm}

Evaluasi pengelolaan $\mathrm{HKm}$ Ujan

Mas Atas dilakukan pada aspek kelembagaan, teknis, sosial ekonomi dan ekologi. Berdasarkan data yang diperoleh bahwa evaluasi kondisi pengelolaan HKm pada masing-masing kelompok tani dan kondisi pengelolaan $\mathrm{HKm}$ secara keseluruhan disajikan pada Tabel 4 dan Tabel 5.

Tabel 4. Evaluasi Kondisi Pengelolaan HKm Pada Masing-masing Kelompok Berdasarkan Aspek Kelembagaan, Teknis, Sosial, Ekonomi dan Ekologi

\begin{tabular}{|c|c|c|c|c|c|c|c|c|c|c|c|c|}
\hline \multirow[b]{2}{*}{ No } & \multirow{2}{*}{$\begin{array}{c}\text { Aspek } \\
\text { pengelolaan } \\
\text { HKm }\end{array}$} & \multirow{2}{*}{$\begin{array}{l}\text { Sko } \\
\text { r } \\
\text { tota } \\
1\end{array}$} & \multicolumn{9}{|c|}{ Jumlah Skor Masing-masing Kelompok Tani } & \multirow[b]{2}{*}{$\begin{array}{c}\text { Kelas } \\
\text { skor }\end{array}$} \\
\hline & & & Smt I & $\mathrm{PJ}$ & KM & $\mathrm{TS}$ & $\begin{array}{c}\text { Smt } \\
\text { II }\end{array}$ & UM & Pnd & $\mathrm{TM}$ & TT & \\
\hline 1. & Kelembagaan & 40 & 28,25 & 28,5 & 28,5 & 28,25 & 28,25 & 28,25 & 28,5 & 28,5 & 28,5 & Baik \\
\hline 2. & Teknis & 40 & 24 & 24 & 24 & 24 & 24 & 24 & 24 & 24 & 24 & $\begin{array}{c}\text { Sedan } \\
\mathrm{g}\end{array}$ \\
\hline 3. & $\begin{array}{l}\text { Sosial, } \\
\text { ekonomi dan } \\
\text { ekologi }\end{array}$ & 20 & 15 & 15 & 15 & 15 & 15 & 15 & 15 & 15 & 15 & Baik \\
\hline & Total skor & 100 & 67,25 & 67,5 & 67,5 & 67,25 & 67,25 & 67,25 & 67,5 & 67,5 & 67,5 & Baik \\
\hline
\end{tabular}

Tabel 5. Evaluasi Kondisi HKm Berdasarkan Aspek Kelembagaan, teknis dan Sosial, Ekonomi dan Budaya

\begin{tabular}{clrcc}
\hline No. & Aspek Kelembagaan HKm & $\begin{array}{c}\text { Jumlah } \\
\text { Skor }\end{array}$ & Jumlah Skor & Kelas Skor \\
\hline 1. & Kelembagaan & 40 & $28.25-28.50$ & Baik \\
2. & Teknis & 40 & 24.00 & Sedang \\
3. & Sosial, ekonomi dan ekologi & 20 & 15.00 & Baik \\
\hline Total Skor & 100 & $72.25-72,50$ & Baik \\
\hline
\end{tabular}

Hasil evaluasi dan analisis terhadap sembilan (9) kelompok tani menunjukkan indikator baik dengan total skor yang diperoleh antara 67,25 sampai dengan 67,50. Berdasarkan ketiga aspek yang dievaluasi semua mempunyai kisaran nilai baik dari aspek kelembagaan dengan skor 28,25 sampai dengan 28,50 (baik), aspek teknis dengan skor 24 (sedang), serta aspek sosial, ekonomi dan ekologi dengan skor 15 (baik). Terjadi perbedaan nilai aspek kelembagaan disebabkan oleh adanya jual beli lahan antar anggota kelompok tani diantaranya pada Kelompok tani Sematung I, Tiga Serangkai, Sematung II, Usaha Maju dan Tanah Tua. Berdasarkan indikator kelembagaan sudah baik tercermin dari bentuk kelompok, struktur organisasi, keanggotaan kelompok areal kerja, mempunyai keanggotaan kelompok dan program kerja. Segi teknis telah melakukan rehabilitasi pada blok budidaya dan perlindungan blok serta untuk segi sosial, ekonomi dan ekologi terlihat dari dukungan pemerintah untuk mewujudkan hutan lestari, pendapatan masyarakat yang meningkat, keragaman tanaman yang bervariasi pada areal dan ketersediaan sumber air.

Nandini (2013) mengatakan bahwa konsep awal pembentukan HKm dilakukan dengan pembentukan dan penguatan kelembagaan, dengan harapan kelembagaan HKm mampu menjadi ujung tombak dalam pengelolaan $\mathrm{HKm}$ pada kurun waktu yang panjang. Pada kenyataannya, kelembagaan HKm yang konsep awalnya telah dirancang secara 
baik tidak dapat menjalankan fungsinya secara optimal karena tidak ada pendampingan secara utuh dari instansi terkait. Pendampingan $\mathrm{HKm}$ hanya dilakukan pada awal kegiatan dandilepas ketika kelembagaan $\mathrm{HKm}$ belum dapat mandiri. Dengan kurangnya sumberdaya manusia yang tepat sebagai pengurus kelembagaan menjadi faktor penambah ketidak berhasilan kelembagaan $\mathrm{HKm}$ dalam mengelola HKm. Untuk mengatasihal ini perlu suatu langkah pendampingan dari instansi terkait yang disertai dengan reformasi kelembagaan
HKm yang telah ada untuk memperbaiki sistem kelembagaan Hkm.

\section{Tutupan Lahan HKm Ujan Mas Atas}

Dari hasil analisis interpretasi citra lansat pada areal IUPHKm Ujan Mas Atas, Kecamatan Ujan Mas, Kabupaten Kepahiang tipe penutupan lahan yaitu kebun campuran dan tegalan. Luas tutupan lahan IUPHKm Desa Ujan Mas Atas pada tahun 2005, 2010 dan 2015 serta luas tutupan lahan terbaru pada tahun 2017. Data ini disajikan pada Tabel 6.

Tabel 6. Data Luas Tutupan Lahan Berdasarkan Interpretasi Citra Lansat

\begin{tabular}{ccccc}
\hline \multirow{2}{*}{ Tahun } & \multicolumn{4}{c}{ Penutupan Lahan (Hektar) } \\
\cline { 2 - 5 } & Tegalan & $(\%)$ & Kebun Campuran & $(\%)$ \\
\hline \multirow{2}{*}{2005} & 67 & 21,04 & 251,5 & 78,96 \\
2010 & 50 & 15,70 & 268,5 & 84,30 \\
2015 & 25 & 7,85 & 293,5 & 92,15 \\
2017 & 18 & 5,65 & 300,5 & 94,35 \\
\hline
\end{tabular}

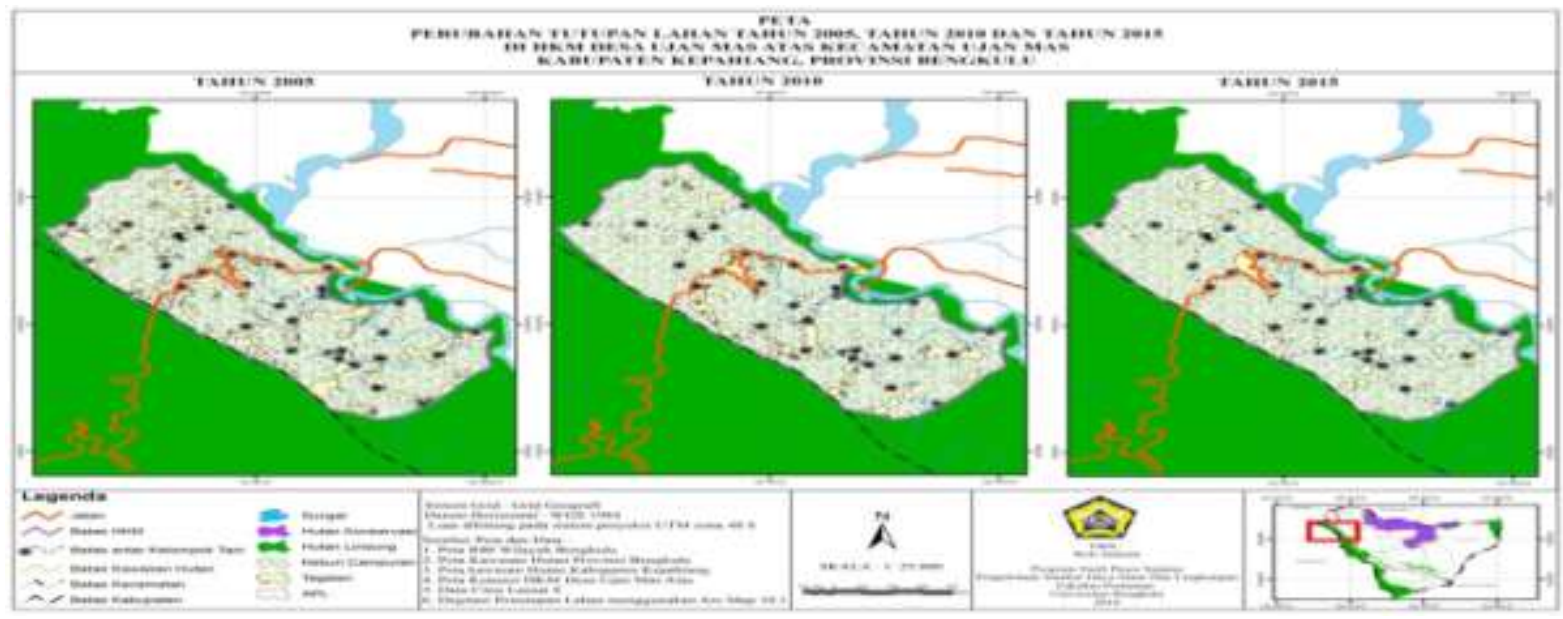

Gambar 1. Perubahan Tutupan Lahan IUPHKm Desa Ujan Mas Atas Tahun 2005, 2010 dan 2015

Berdasarkan Tabel 6 pada tahun 2005, luas tipe penutupan lahan kebun campuran adalah 251,5 hektar (78,96\%) dari luas total HKm Ujan Mas Atas 318,5 hektar. Sementara luas tipe penutupan lahan tegalan adalah 67 hektar $(21,04 \%)$. Laju perubahan tutupan lahan yang mengalami peningkatan adalah tipe penutupan lahan kebun campuran. Tutupan lahan kebun campuran mengalami peningkatan tahun 2015 sebesar 25 hektar (9,31\%) lebih luas dibandingkan dengan tahun 2010 sebesar 17 hektar (6,76\%). Laju perubahan tutupan lahan pada tahun 
2017 hanya sebesar 7 hektar (2,39\%). Hasil ini sesuai dengan yang dikemukan oleh Haryadi (2011) dalam Puspasary (2017), mengatakan bahwa hutan kemasyarakatan merupakan suatu sistem pengelolaan hutan yang ditujukan untuk meningkatkan kesejahteraan masyarakat di dalam dan sekitar kawasan dengan tetap memperhatikan kelestarian fungsi hutan. Perubahan tutupan lahan IUPHKm Desa Ujan Mas Atas disajikan pada Gambar 1.

\section{KESIMPULAN}

Berdasarkan hasil dan pembahasan penelitian ini, maka dapat disimpulkan bahwa :

1. Hasil evaluasi Pengelolaan IUPHkm Desa Ujan Mas Atas yang diperoleh berdasarkan data dari masing-masing kelompok tani dalam aspek

\section{DAFTAR PUSTAKA}

Arikunto, S. 2011. Prosedur Penelitian Suatu Pendekatan Praktik. Rineka Cipta. Jakarta.

Badan Pusat Statistik Provinsi Bengkulu. 2017. Provinsi Bengkulu Dalam Angka 2017. Bengkulu.

Dinas Lingkungan Hidup dan Kehutanan Provinsi Bengkulu. 2017. Rekapitulasi Kegiatan Pencegahan dan Pengamanan Hutan. Bengkulu.

Kementerian Lingkungan Hidup dan Kehutanan. 2016. Data Penutupan Lahan Tahun 2011-2016. Jakarta.

Kementerian Lingkungan Hidup dan Kehutanan Republik Indonesia. 2016. Peraturan Direktur Jenderal Perhutanan Sosial dan Kemitraan Lingkungan Nomor P.12/PSKL/SET/PSL.0/11/2016

Tentang Pedoman Verifikasi Permohonan Izin Usaha Pemanfaatan Hasil Hutan Kemasyarakatan IUPHKm). Jakarta.

Nandini, R. 2013. Evaluasi Pengelolaan Hutan Kemasyarakatan (HKm) kelembagaan berada pada kondisi baik dengan skor 28,25-28,50, aspek teknis berada pada kondisi sedang dengan skor 24 serta aspek sosial, ekonomi dan ekologi juga pada kondi baik dengan skor 15 . Jadi total skor yang diperoleh dari evaluasi pengelolaan IUPHKm Desa Ujan Mas atas secara keseluruhan adalah dalam kondisi baik dengan skor 67,25.

2. Tipe penutupan lahan dikelompokkan menjadi 2 (dua) yaitu kebun campuran dan tegalan. Laju perubahan tutupan lahan yang mengalami peningkatan adalah kebun campuran. Tutupan kebun campuran mengalami peningkatan tahun 2015 sebesar 25 hektar (9,31\%) lebih luas dibandingkan dengan tahun 2010 sebesar 17 hektar $(6,76 \%)$.

Pada Hutan Produksi dan Hutan Lindung di Pulau Lombok. Jurnal Penelitian Hutan Tanaman Vol. 10 No. 1.43-55.

Pemerintah Daerah Kabupaten Lampung Barat. 2005. Keputusan Bupati Lampung Barat Nomor 225 Tahun 2005 Tentang Panduan Teknis Penghitungan Skor dan Bobot Kriteria dan Indikator Monitoring dan Evaluasi Pelaksanaan Program Hutan Kemasyarakatan di Kabupaten Lampung Barat. Lampung.

Puspasary, E. 2017. Aspek Pendapatan Pada Sistem Agroforestry di Areal Kerja Hutan Kemasyarakatan (HKm) Kabupaten Lampung Barat, Provinsi Lampung. Universitas Lampung. Bandar Lampung.

Soewadji, J. 2012. Pengantar Metodologi Penelitian. Mitra Wacana Media. Jakarta.

Sugiono. 2015. Statistik Nonparametris Untuk Penelitian. Alfabeta. Bandung. 
Sulistyorini, I.S., M. Edwin, A.S. Arung. 2016. Analisis Kualitas Air Pada Sumber Mata Air di Kecamatan Karangan dan Kaliorang Kabupaten Kutai Timur. Jurnal Hutan Tropis. Vol. 4. No. 1.

Surat Keputusan Bupati Kepahiang Nomor 470 Tahun 2009 tanggal 10 November 2009 tentang pemberian Izin Usaha Pemanfaatan Hutan Kemasyarakatan (IUPHKm) Kepada Kelompok-kelompok Tani Pada Kecamatan Ujan Mas,
Kecamatan Kepahiang, Kecamatan Seberang Musi di Kabupaten Kepahiang. PEMDA Kepahiang. Kepahiang.

Surat Keputusan Bupati Lampung Barat Nomor 11 Tahun 2004 tanggal 11 Februari 2004 TentangPanduanTeknisIndikatorda nKriteria Monitoring dan Evaluasi Pelaksanaan Program Hutan Kemasyarakatan di Kabupaten Lampung Barat. PEMDA Lampung Barat. Liwa. 